\title{
Sing a New Song
}

PRESIDENTIAL ADDRESS DELIVERED BEFORE THE 72nd ANNUAL MEETING

OF THE AMERICAN SOCIETY FOR CLINICAL INVESTIGATION,

\author{
WASHINGTON, D. C., 11 MAY 1980
}

Jesse Roth

National Institute of Arthritis, Metabolism, and Digestive Diseases, Diabetes Branch, National Institutes of Health, Bethesda, Maryland 20205

You, the members of The American Society for Clinical Investigation, have honored me and my fellow officers by electing us and entrusting us with the leadership of the society. We wish to thank you for the privilege and to account to you for our terms in office. I would like to review briefly a few of our accomplishments, some of the problems that we see, and the modest experiments we have undertaken. Also I am going to assign several jobs to every member of The American Society for Clinical Investigation and to all members of the clinical research community. Finally, the highlight of this morning's program will be the next speaker, Professor Rolf Luft, who will discuss "Excellence and creativity in medical science." (1).

\section{Politics}

Let us talk for a moment about the three clinical research societies and their relationship to the outside world. I would like to bring up politics in the broad Aristotelian sense of the word. There is no way we can escape politics. The American Federation for Clinical Research has appreciated this and has acted accordingly. The two older societies, The Association of American Physicians and The American Society for Clinical Investigation, have been hesitant. We, the three societies, are the voice of clinical investigation. We must speak out appropriately.

First, let us consider the problem of "lesser politics." We are being called upon increasingly by umbrella organizations of medical and academic groups to represent the voice of clinical research. We must respond by having skilled delegates who will go to these meetings and speak for the clinical research societies and the clinical investigation community.

Second, let us consider "greater politics." I and the other officers of The American Society for Clinical
Investigation have accepted the challenge presented to us by our president last year - that we must be involved in the greater politics of the American system. On Friday, May 9th, in the Rayburn Building of the House of Representatives, we sponsored a Clinical Research Showcase, a joint project of the three societies in collaboration with National Health Policy Forum, a nonprofit group that promotes communication within government on health-related matters. The congressional sponsor was Representative Tim Lee Carter, M.D., of Kentucky. Twelve scientists from the three societies presented their work to an audience of interested government and media representatives. This first experiment was very well received and may serve as the basis for an annual event.

The second item concerns legislation now before Congress. House and Senate bills now under consideration represent very serious threats to biomedical research. The fliers we distributed and the legislative desk we set up at the entrance to the exhibit area are to make it easy for you to respond-to write to your senators and representatives. Remember, there is a great American tradition-when Washington steps on our toes, we are supposed to yell "ouch." If Washington steps on our toes and we remain silent, we are, in fact, undermining the American system. There will be a Sunday evening chat at which the officers of the three societies will present their concerns about key provisions of these two bills to members of Congressman Waxman's staff, who, as you know, play a major role in this legislation.

\section{The American Society for Clinical Investigation (ASCI)}

Now I wish to consider ASCI itself. The society has three components-The Journal of Clinical Investiga- 
tion, this joint meeting, and you, the membership. We are justly proud of the journal and of this meeting. I wish to focus the rest of my attention on the membership - in the present and in the future.

Present membership. Clearly, the membership is a vital element of this society. I am deeply concerned that for a society of young investigators we have become much too parochial. The catchment from which we derive our membership has become much too narrow; it is largely restricted to internal medicine in the traditional sense. We must encourage the election and participation of excellent investigators from other clinical specialties, including pediatrics, neurology, psychiatry, and dermatology as well as obstetrics and gynecology, surgery, and the surgical specialties.

Equally important, we must recruit physician investigators who are not in clinical departments. I queried physician investigators who are leaders in my own areas of research whose credentials for this society are impeccable. A large number neither attend our meetings nor are members of this society. When I inquired why they were not members, I learned that for the most part they had never been asked. Would they join? Now, they would not join, but had they been asked in their thirties, they think they probably would have accepted the opportunity.

To illustrate how narrow we are, I reviewed the Nobel Prize winners to see how many of them have been associated with our society. Before I present these data, let me remind you of the prerequisites for membership in ASCI: (a) M.D. degree, $(b)$ based in North America, and $(c)$ under $45 \mathrm{yr}$ of age. From 1901 to 1979 , there have been a total of 126 Nobel Prize winners in physiology or medicine, of whom 59 have been North Americans (Table I). If we subtract the North American who was awarded the prize in 1912, when the Society was just being founded, we are left with 58. Among these 58 North Americans were 34 M.D. scientists, of whom only 7 have been members of ASCI. Thus, of North American physicians who have won Nobel Prizes in physiology or medicine, only about $20 \%$ have been members of our society. It does not appear to me that ASCI is such an elite "hot shot" group after all.

To correct this deficiency, I suggest that ASCI should assume leadership in recruiting superior M.D. scientists for the clinical research meetings. We must identify rising young stars in their thirties. At that time of life, their meeting habits have not yet ossified, and the charisma of ASCI, which may have touched them during medical school and house staff days, has not yet worn off completely. If in this narrow time frame, we invite them to become members of the society and to attend our meetings, hopefully, many of them will find our meetings to be an appropriate venue for presentation of their scientific works, which should profit all of us.
TABLE I

Nobel Prize Winners for Physiology or Medicine

(1901-1979)

\author{
$126=$ Total \\ $-67=$ Outside North America \\ $59=$ Total North Americans \\ $-1=$ Awarded in 1912 (too early for ASCI) \\ $58=$ North Americans (1923-1979) \\ Not eligible for ASCI \\ 23 Ph.D. \\ 1 no doctoral degree \\ Total eligible for ASCI \\ 34 M.D. \\ 7 associated with ASCI/34 eligible for ASCI $=21 \%$ \\ 1934 W. P. Murphy \\ 1934 G. R. Minot \\ 1950 P. S. Hench \\ 1954 F. C. Robbins \\ 1956 D. W. Richards \\ 1959 A. Kormberg \\ 1976 B. S. Blumberg
}

Thus, our first assignment to the ASCI membership is to seek out excellent M.D. investigators beyond our traditional areas and nominate them for membership in this society. If our members respond to our plea and bring forth nominations of people from outside our traditional membership, the ASCI Council is committed to act promptly to accept new members beyond the present limit of 80 per year. Moreover, to encourage the recruitment of new members, we have introduced a clearer and simpler nomination form.

Honorary membership. Further along these lines, we have introduced this morning a by-law amendment to be voted on next year that would create a new class of members, designated "honorary members." To this class we may elect up to five people a year who are outstanding in clinical investigation but who fail to meet any or all of the formal requirements that I have mentioned. These people would have the rights and privileges of an emeritus member. Hopefully, these honorary members would be drawn closer to these meetings and would participate more fully. It would also allow us, the society, to correct some of the errors we may have committed in failing to elect some outstanding investigators before they reached age 45 , and to elect outstanding leaders in clinical investigation who do not have an M.D. degree. Experiments to broaden our scientific membership (along with experiments to broaden the scope of our scientific programs) can only lead to more exciting and enriching meetings.

Future membership. Let us talk about future ASCI membership. Clearly, the future of ASCI depends on 

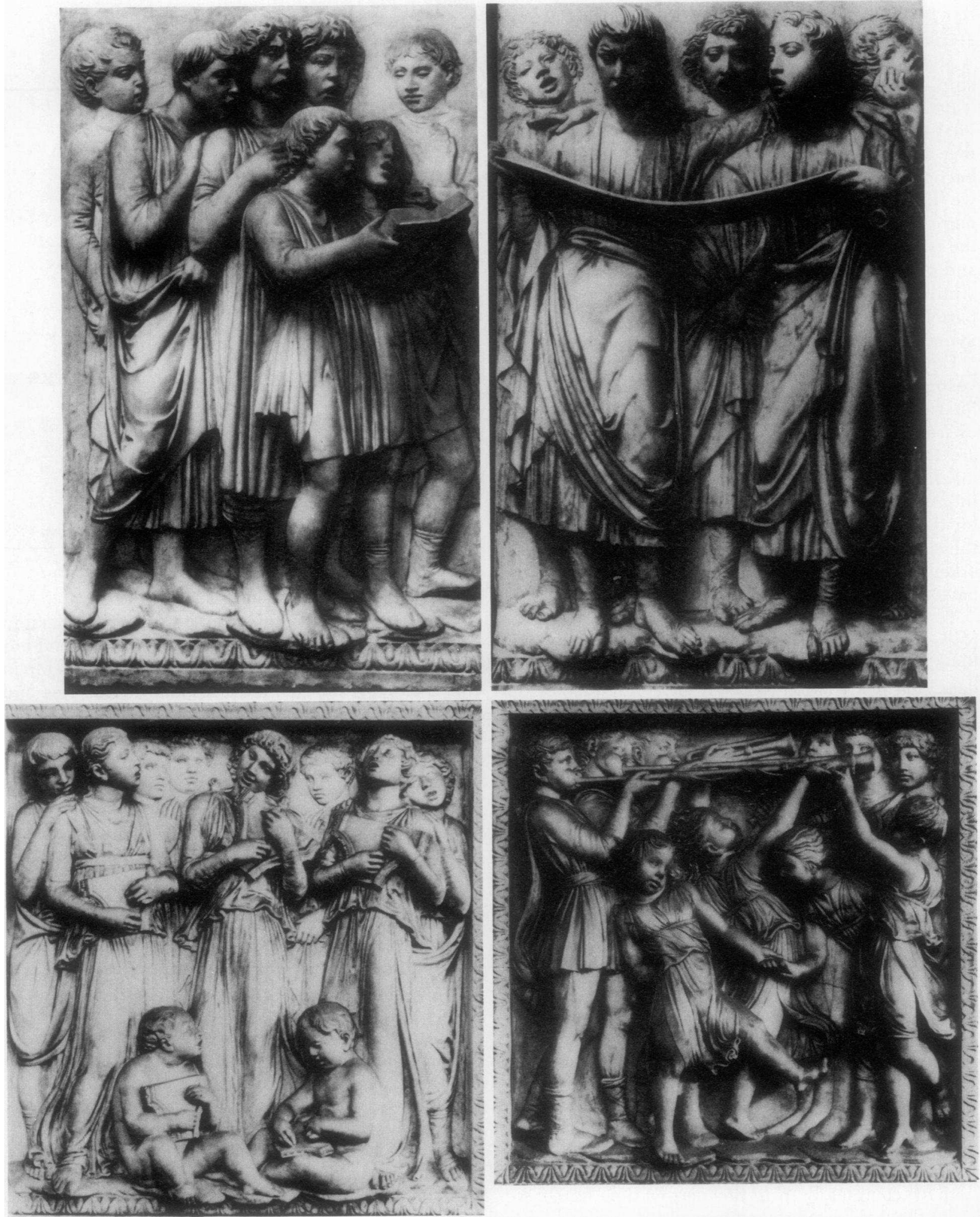

FIGURE 1 The figures represent bas-reliefs by Luca della Robbia from the singing gallery installed in the Cathedral in Florence, Italy, in 1438 to illustrate Psalm 150, and are reprinted with the permission of Arti Gafiche Ricordi, Milano, Italy. 
the future of the clinical research community in America. What part of our future is in the hands of others? Obviously, the federal government plays a decisive role, but our influence on the federal government is intermittent, uncertain, and indirect.

What can we do directly? You and I have a unique opportunity to recruit clinical investigators. Every day you and I come in contact with the clinical investigators of the future. They are our medical students, our house officers, and our fellows. And what do we do when we talk to these young physicians about research? We complain! We complain about the fate of clinical investigation. We recall the golden age of the 1960s. We hark back to the halcyon days of yore. We complain about funding. We complain that we are not appreciated. We complain about government regulations, the Food and Drug Administration, and paper work. All we do is complain.

What must mystify the young physician is why you and I continue to do what we are doing. If the life of the investigator is so miserable, why do you and I persist? Is this an annual gathering of 3,000 masochists? Unlike our Ph.D. colleagues in science, you and I, with our M.D. degrees, can quit and do something else. Why don't we quit? Because, despite all the problems, we are having a remarkably good time. In fact, we are among the luckiest and most fulfilled people who have ever lived. Consider for a moment all the people who have ever lived, or all those now living, or just consider the U. S. at large, or let us even narrow our consideration to the more limited community of creative individuals. Compare the lot of the medical investigator, pursuing his or her creative goals, with that of other academicians or the composer, the musician, the poet, or even architects and writers. You and I are supported in pursuing our creative goals better than almost anybody else, and, more than anybody else, we are able to pursue our creative goals and maintain our professional and creative integrity.

My challenge to you is to stop for a few minutes and think about the joys and satisfactions that you derive from your academic pursuits. Define and catalogue these joys: the joy of chipping a flake of truth from the infinite mountain of the unknown; of discovering a new world previously hidden in your microcosm of research; of taking an idea and giving it form, from the first experiment to a coherent corpus of published works; of defining a new mechanism for a disease or recasting the diagnostic or therapeutic approach to a medical problem. Equally important, think about the satisfaction you derive from bringing forth children in an intellectual way, the joy of watching a young physician enter into the laboratory knowing nothing about research, and your joy as a parent, seeing that same young physician 5 or $10 \mathrm{yr}$ later emerge as an expert, a leading investigator, completely independent and creative.
Now, go and tell every young physician about your joys and satisfactions in your academic pursuits. Tell them at every opportunity and in great detail. Do not complain to them-just tell them the joys. Tell you complaints to your congressman, to your administrator, to your boss, to your colleagues, or your spouse, but do not complain to the young physician. If the young people ask you about the problems of clinical research, tell them, but do not volunteer the information. You and I have done considerable harm to the future of clinical investigation by complaining to the young people. I think we can have a direct impact on the future of clinical investigation by changing our song. Stop singing the blues. Instead, recount to the young physicians our joys, our sense of creativity and our fulfillment.

Since this is Sunday morning, and Mother's Day, as well as a very meaningful occasion for me personally, I wish to offer a short prayer before giving you my concluding summary. For the occasion, I have turned to the Psalms ${ }^{1}$ - not for a psalm of lamentation or a psalm of grief and mourning but for a song of joy (Fig. 1).

SING A NEW SONG

שִירוּ שִיר חָדָט

SHOUT FOR JOY הָריעוּ -

BREAK FORTH AND SING

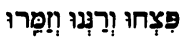

SING PRAISES 1าอุ!

WITH THE HARP AND THE VOICE

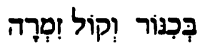

WITH TRUMPETS AND WITH HORNS

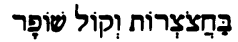

SHOUT FOR JOY הָריעוּ - הרים

In summary, I have tried to review briefly for you a few of our accomplishments - to highlight some of our shortcomings and some of the modest experiments we have engaged in to reduce these shortcomings. More important, I have asked you to participate actively in the political process in the American way and to join us in strengthening the membership of ASCI and of the clinical research community at large-both in the present and for the future. Finally, I have asked you to join me in singing a new song-a song of joy - to the promising young physicians of today who will be our clinical investigators of tomorrow.

\section{REFERENCE}

1. Löw, H., and Luft, R. 1980. Excellence and creativity in medical science. Clin. Res. 28: In press.

${ }^{1}$ The text was adapted by the author from Psalm 98: 1, 4-6, based on versions published in (a) The Traditional Prayer Book for Sabbath and Festivals, edited and translated by David de Sola Pool, (New York: The Rabbinical Council of America, Behrman House, 1960), pp. 35-36 and (b) The Psalms, edited by A. Cohen, London: Soncino Press, 1945, pp. 320-321, and (c) The Authorized or King James Version (1611) (Cleveland: World Publishing Co.,), pp. 535-536.

Presidential Address 